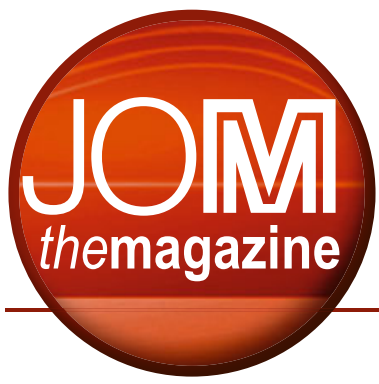

\title{
meet a member
}

\section{Career as a Potter Fires Marcus Young's Imagination as a Scientist}

\section{Lynne Robinson}

As a professional artist specializing

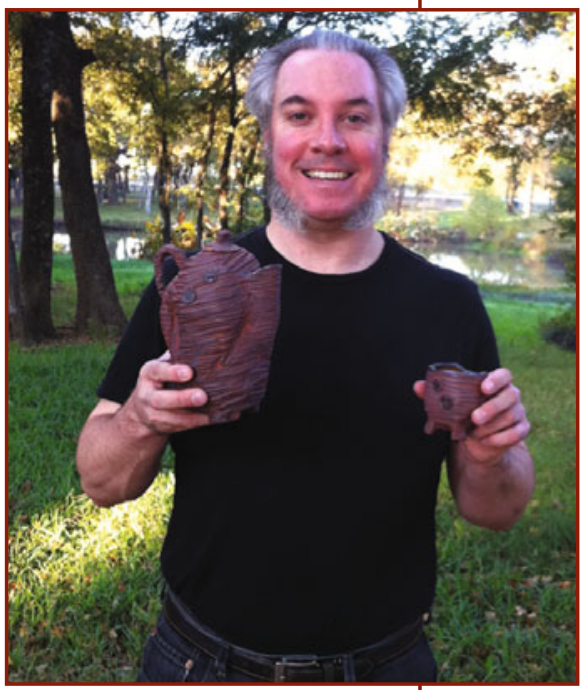

in ceramics, Marcus Young

was doing experimental

materials science without

actually knowing that the field

existed. "I was fascinated

by the challenge of making

three-dimensional objects

and working with materials,"

said Young, now assistant

professor at the University

of North Texas (UNT) in

the Materials Science and

Engineering Department.

"Because of my interest in

the process, I was purchasing

raw chemicals and mixing my

own clays, slips, glazes, and

Marcus Young holds two pieces from his Stone Teapot Cup Series.

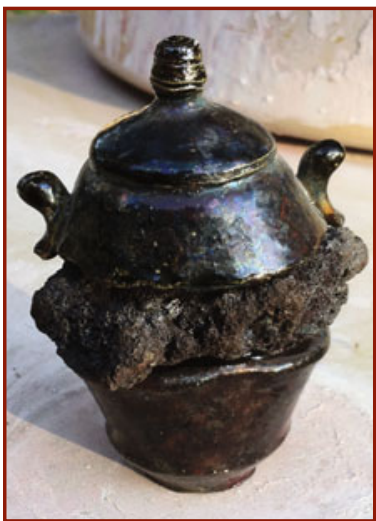

For this piece, Young inserted lava rock between two sections that had been thrown separately. The pot was then dried and glazed before once-firing in a small Raku kiln. "It took some testing to get the right mixture that matched the shrinkage/contraction rate of the lava rock with the clay to avoid cracking," explained Young. stains. I also performed extensive testing on small samples, and would adjust the chemical ratios to study visual effects of phenomena like blistering, crawling, crazing, peeling, pinholing, pitting, and shrinkage."

Initially enrolled in college as a biology major on full scholarship, Young determined that he wanted to pursue a career in studio arts instead, eventually graduating from UNT with Bachelor's in Fine Arts degrees in both ceramics and sculpture. Said Young, who had been interested in art since a toddler, "I would say that a person doesn't choose to be an artist. I actually tried to resist this calling because I'm also pragmatic. I didn't see it leading to a long-term career, but that didn't change the fact that I really

While creatively fulfilling, Young noted that "making a living as an artist is a hard life." After interning a summer with a professional artist, Young started working as a "production potter," traveling and making objects constantly to sell at craft fairs and galleries, and enjoyed making art." taking on consignment, contract, and commissioned work whenever possible. In time, he set up his own studio in his apartment living room with equipment he acquired from an estate sale. As he grew more commercially successful, Young felt that his art career had evolved into "being more of a business" and decided that he wanted to take a different direction.

Young had excelled in chemistry and math in both high school and college, prompting him to consider chemical engineering as his new career direction. After taking an introduction to materials science course, Young said, "I realized that this was exactly what I had been doing as an artist and switched majors almost immediately." He subsequently earned a B.S. from the Colorado School of Mines in Metallurgical and Materials Science and Engineering and a Ph.D. in Materials Science Engineering from Northwestern University.

Rather than experimenting with clay and glazes, Young said he now focuses his research on the development, processing, and characterization of structural alloys, specifically, shape memory alloys, refractory and reactive metal alloys, and high entropy alloys, and their porous and metal matrix composite counterparts.

His art, however, remains closely intertwined with his work as a materials scientist. As an example, he points to unique insights into alloy development that he has gained through his handson experiences with materials. "When melting alloys, it is often possible to see macrostructure and phases forming in the melt as the temperature changes. Based on these observations, it is possible to control the final structure by examining these changes visually," he said. "This 
information gives clues as to how solidification occurs microscopically and can aid in producing better alloy melts."

"I find it interesting that, from an artistic perspective, visually stimulating alloys are generally undesirable from a materials science and engineering perspective," he added.

Inspired by that particular juxtaposition of artistic and scientific thought, Young and a professor in UNT's College of Visual Arts and Design are developing a Materials Science of Metalsmithing course that pairs artists and engineers to explore these and similar types of phenomena. He is also working on proposals for art projects involving local schools that incorporate materials science concepts.

Young likewise draws extensively on his art background when teaching conventional materials science and engineering classes. "I recently taught my students about the crying of tin due to twinning. I learned of this phenomenon in art school when working with tin castings, although at that time, I didn't know why it made that sound. I just knew that it did," Young recalled. "It wasn't until I entered materials science and the instructor at the time started talking about twinning in tin that I made the connection. For me this wasn't just a description in class, but something I had already experienced. As an instructor, I try to bring these types of experiences to my students in the classroom."

"My artistic career has definitely evolved with my engineering career," Young said, "as my understanding of the processing has become much deeper."

Each month, JOM profiles a TMS member with a particular hobby, interest or experience to share. To suggest a candidate for this feature, contact Lynne Robinson at Irobinson@tms.org.

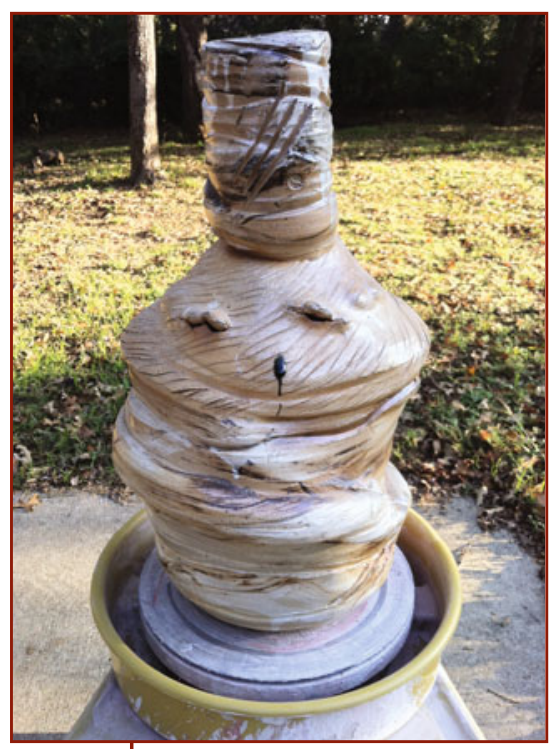

This very large piece of Young's was high fired in a hybrid salt/wood/gas kiln. The brick on the top wall of the kiln formed a green glass over several firings that ended up dripping on the very front of the pot.

\section{member news}

\section{Subra Suresh Elected to Institute of Medicine}

Subra Suresh, President, Carnegie Mellon University (CMU), and 2000 TMS Fellow, was elected to the U.S. Institute of Medicine (IOM) in October. Having been previously elected to the National Academy of Sciences and the National Academy of Engineering, he is one of only 16 living Americans and the first CMU faculty member to be inducted to all three U.S. national academies. Suresh was named to

\section{Gregory Olson Named to Royal Swedish Academy}

Gregory P. Olson, Chief Science Officer, QuesTek Innovation LLC, and company co-founder, was elected to the Royal Swedish Academy of Engineering Sciences as a foreign associate. Olson is also a Walter P. Murphy Professor of Materials
IOM in recognition of his research into cell mechanics related to malaria, blood diseases and certain types of cancer.

Suresh has also been elected to the American Academy of Arts and Sciences, as well as analogous organizations in Spain, Germany, Sweden, and India. He is a fellow or honorary member of all the major materials research societies in the United States and India.

Science and Engineering at Northwestern University, where he teaches, leads an active group researching computational materials design, and directs the Materials Technology Laboratory/Steel Research Group.

\section{Rajendra Bordia Leads Clemson MSE Department}

Clemson University has named Rajendra "Raj" Bordia chair of the Materials Science and Engineering (MSE) Department. Bordia comes to Clemson from the University of Washington, where he has been since 1991, chairing the metallurgy and ceramics program from 1998 to 2005. Prior to that, he was a research scientist in the Central Research and Development Department of DuPont.
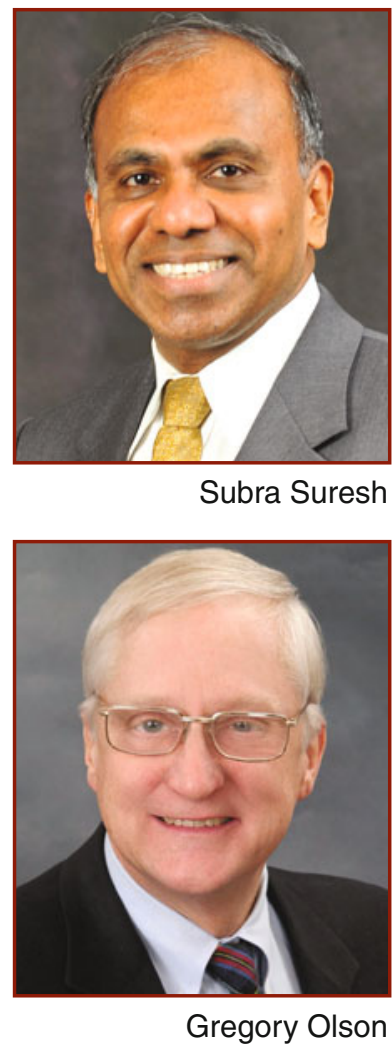